Available online at: http://proceeding.rsfpress.com/index.php/pss/index

LPPM UPN “Veteran" Yogyakarta Conference Series

Proceeding on Political and Social Science (PSS)

Volume 1 Number 1 (2020): 200-207

\title{
Coaching Communications Model For Improving Athlete Achievement
}

\author{
Edwi Arief Sosiawan, Tri Saptono \\ Universitas Pembangunan Nasional Veteran Yogyakarta \\ Email address sadelisahadati@gmail.com,Email address edwias@upnyk.ac.id
}

\begin{abstract}
In general, the trainer's technical abilities must be mastered by the trainer. The reason is that those who become coaches are generally former athletes. They are also have training certificates from various training and coaching clinics. However, the ability to communicate in coaching is not necessarily fully mastered by most coaches. The purpose of this research was to add theoretical development about the study of sports coaching communication, especially in the process of athlete physical and mental training by using descriptive qualitative research approaches. The results showed that the coaching communication patterns developed in the training process and outside the training. The form of coaching communication during and outside training is generally face-to-face. The method used in coaching communication is to use lectures and demonstrations as well as to involve video media to further stimulate achievement motivation for each athlete. The approach taken in coaching communication is an open, family, and personal approach. The choice of coaching communication methods has been proven to be able to motivate and build athletes' self-confidence and athletes can accept and interpret the instructional messages conveyed and desired by the coaches. Suggestions and recommendations that can be given in this research are on the certification of trainers for each sports trainer.
\end{abstract}

Keywords: ideal model, coaching communication, athlete achievement

\section{INTRODUCTION}

This is an open access article under the CC-BY-NC license.

In general, the technical abilities to train have been mastered by the coaches because those who are coaches are former athletes. They also a person who already has training certificates from various kinds of upgrading, training, and coaching clinics. However, the ability to communicate in coaching is not necessarily fully mastered by most coaches. Apart from the absence of special coaching communication training facilities in upgrading, training, and coaching clinics it is also because the appointment of trainers is generally more prioritized on branching technique skills. If this condition has been allowed hence the effort to increase the performance of athletes in the Sleman Regency will experience imbalance. In other 
words, individual athletes are not necessarily able to master good and correct techniques on the one hand and in general, the accumulated sports performance will not increase and will tend to experience stagnant conditions. This of course will be an obstacle in increasing athletes' achievement in Sleman Regency and Yogyakarta Province which will affect achievement at the national level, in addition to the short-term goal of becoming the overall champion in the PORDA event in 2021 will not be achieved.

Looking at the perspective of coaching communication problems is an important factor for coaches in the process of physical and mental training to improve athlete performance. Therefore, the formulation taken for this study is "What is the ideal coaching communication model to increase the achievement of athletes in the sport in the KONI Sleman Regency? " This research tries to look from two perspectives, namely the process of instructional communication and coaching because In general the study of coaching communication is only seen from the perspective of interpersonal communication and does not specifically study coaching communication.

\section{LITERATURE REVIEW}

\section{Effective communication coaching}

Effective coaching communication paves the way for skills at a higher level regarding the quality of athletes (Davis etc, 2019). This means that improving the technical quality of athletes does not only rely on the trainer's personal experience and background but also on an effective communication model that allows athletes to receive, process information, and transfer knowledge in a more efficient way (West, 2016, 13).

According to Michael Hall $(2008,82)$, effective communication can help coaches improve athlete self-regulation which in turn contributes to improving athlete performance. Athlete self-regulation refers to a complex process that provides the ability to monitor athletes' thoughts and behavior and enables them to respond appropriately to the sports environment. That is why it will be very important for coaches to learn about effective communication structures that equip athletes to act according to the trainer's training system (Rosca, 2010).

Trainers communicate with athletes for a number of reasons and the goals according to (Weinberg \& Gould, 2003) are to persuade and persuade, evaluate, inform, motivate, and inspire and overcome problems. The main principle of effective coaching communication is finding out to understand the other party and then trying to be understood (Covey, 1990). To get an effective coaching message, the first thing is to know the basics of sending an effective message which includes; a) Clear and concise; Coaches must use simple and specific messages so that players know what the coaching message is intended for. b) Honest; honesty can create an environment of mutual trust between coach and athlete. Honesty is meant here is praise and criticism of the competence of athletes during training or during the competition. c) Repetition/repetition; often a disruption in coaching communication occurs because the athlete forgets what the coach has said.

The second thing the trainer must understand is to be aware of the external factors that can affect the way messages are sent and received. The third ineffective coaching 
communication is ensuring messages are received. As stated earlier, communication is a two-way street; the recipient is just as important as the sender as it is imperative that athletes receive the message and instructions. Fourth, the coach provides encouragement, motivation, and space for feedback from athletes to coaches so that misunderstandings do not occur. Fifth, coaches must adapt to athletes because athletes generally receive messages differently depending on their experiential, social, cultural, and educational backgrounds and psychological conditions (Gabriel, 2016, 32-33).

\section{RESEARCH METHODOLOGY}

This study used a qualitative approach that was described as descriptively. This approach was chosen in order to reveal in-depth about the strategies and patterns of coaching communication used in athletes' physical and mental training. Bogdan and Taylor (Kaelan: 2012) said the qualitative research method is a research procedure that produces descriptive data in the form of words, notes related to meaning, value, and understanding. In addition, qualitative methods always have a holistic nature, namely the interpretation of data in relation to various possible aspects.

\section{FINDING AND DISCUSSION}

This study looked at the coaching communication carried out by Badminton, Dance, Karate, and Pencak Silat sports. Each of them has its own character in the training process and coaching communication. For clarity, the coaching communication model from each sport which is used as research subjects are as follows:

\section{Badminton sports}

The badminton sport in Sleman Regency has been a regular and dominant champion in the PORDA DIY event from 2009 to 2019. Therefore, this sport is always the primadonna of gold panners in every PORDA DIY event. The training process is carried out by the badminton sport which is managed by the Indonesian Badminton Association (PBSI) of Sleman Regency. The training consists of four training a week which include drill, receipt, game training systems and on weekends physical training is carried out interspersed with games.

The communication pattern of the PBSI Sleman trainers' coaching with Puslatkab athletes is characterized by openness not only during training / in the field but also outside the training schedule. The form of openness of the trainer during the training process is to try to be honest with the statement messages that are conveyed to athletes, such as the importance of training and motivation in achieving achievement. In addition, to support for openness in communication, positive behavior and attitudes were also carried out by PBSI Sleman district trainers in coaching communication through positive encouragement when delivering training programs during the training process. The PBSI coaches in Sleman Regency also communicate openly the analysis of the weaknesses and strengths of each athlete which has the aim that the athletes can believe in their abilities and be able to overcome and improve their weaknesses during training and during competitions. 
If then look at the obstacles in coaching communication carried out by PBSI coaches in Sleman regency to badminton athletes in Sleman regency are the catching power of each athlete and their educational background. Capture power is related to the level of intelligence of each athlete and is related to the level of education of the athlete. This was felt by the PBSI trainers according to the fact that they had to provide reps in providing material and examples of exercises. The difference in interpreting the coaching message here makes the coaching communication experience disruptive which is overcome by the repetition of training material modeling conducted by PBSI trainers in Sleman district.

\section{Dancesport}

The dancesport follows the organizational pattern at the international level, namely the International DanceSport Federation (IDSF) which has a Latin characteristic dance form category and standard ballroom characteristics. The dancesport branch of Sleman Regency has begun to strengthen its progress when it has succeeded in becoming the overall champion of the XV DIY PORDA, after previously since 2011 it only stood in overall champion 3. The dancesport branch managed by the Indonesian Dancesport Association (IODI) ) Sleman Regency.

IODI Sleman Regency carries out a one-year training program prior to the implementation of the PORDA. The dance team trains physically and mentally 4 times a week. The physical training program applied is physical training that leads to endurance or endurance for athletes with a target of 100 percent each training. The mental training program implemented by the IODI trainer in Sleman Regency is in the form of sports psychology coaching every Sunday by inviting sports psychology experts.

The communication of the training in the dancesport branch is direct during the implementation of the training, this is an efficiency measure considering the number of trainers in the IODI dance sport in Sleman Regency is only one person. Generally, communication that is carried out in the training process is using non-verbal language, because in the training system the trainer also provides direct examples. Through an informal atmosphere, the IODI Sleman district dance coaches provide direct training program instructions at the training location. Trainers and athletes communicate at a close distance, by means of a dance coach giving instructions to athletes through gestures and body language to further clarify the explanation of training instructions that are conveyed orally.

The communication strategy applied by the IODI dance sport coach in Sleman Regency is through a personal approach for athletes who have obstacles in the training process or in understanding training. Another approach is the freeing approach in the form of communication between coaches and athletes in a forum to solve a problem related to training problems or other non-technical problems.

In contrast to badminton, dance sport has the criteria for athletes in their teens or under 16 years of age, so that mood and fatigue sometimes become obstacles in the communication process. This makes the coaching communication barrier in the sport of dance purely psychological. To overcome these obstacles, the trainers in dance use a personal approach and try to take a personal approach that tends to be pedagogical, considering that most dance athletes are still in their teens. 


\section{Pencak Silat}

The Indonesian Pencak Silat Association (IPSI) as the parent of the sport of Pencak silat has organizational goals for regeneration, preservation, and finding new athletes of Pencak silat. The achievements during the PORDA DIY IPSI Sleman Regency have been glorious because since 2013 they have always been the overall champion until the XV DIY PORDA in 2019. The key to success in fostering the achievements of the IPSI Sleman Regency Pencak silat sport is the number and quality of the trainer's competence.

Pencak silat as a martial arts sport has a training pattern not only physically, techniques, tactics, and strategies but also requires the leadership of the coach in the training process. The attitude and leadership of the coach in communicating to handle athletes are expected to be able to boost an athlete's performance. IPSI Pencak Silat athletes in Sleman Regency are generally students and students. It can be said that they are relatively able to carry out regular exercises.

In general, the coaching communication pattern carried out by IPSI Sleman Regency is to use a family approach to athletes which aims to avoid gaps between coaches and athletes. This familial approach is conveyed both inside and outside of training. Generally, the communication process in training includes information about the training program, the pattern being carried out, and information about the correctness of the technique. Providing information from coaches to athletes can run well because it is carried out in a family manner so that it feels closer, relaxed, and remains principled according to the character of each athlete.

Through a kinship approach in coaching communication, it allows for intimacy and comfort between coaches and Pencak silat athletes. The form of coaching communication between IPSI coaches in Sleman Regency and athletes combines verbal and non-verbal communication proportionally. Both are used but prefer nonverbal communication during the training process. The attitude of openness to verbal language is reflected in words such as a coach who is willing to accept input during the training evaluation process and nonverbal language which is reflected in body movements such as embracing. This aims to make athletes feel calmer when experiencing difficulties during walking training.

Karate

The karate sports branch is part of the Indonesian Karate-do Sports Federation (FORKI). In Sleman Regency itself, the sport of karate has contributed a lot to medals since PORDA DIY in 1989. Since 2017 FORKI Sleman's achievements can increase to second place in PORDA to XIV in 2017 and culminating in becoming overall champion 1 at PORDA DIY to XV in 2019. Besides that, the achievements outside the PORDA DIY were also the overall champion in the open championship and the peak achievement was being able to pass one athlete to the PON event in 2021.

Efforts made by FORKI in Sleman regency to improve karate performance are technical training 3 times a week and physical training once a week. At a high level, such as facing a national and tiered championship, the training intensity is increased to 4 times a week. The number of trainers owned by FORKI in Sleman district is four consisting of the kata trainer and the Kumite trainer. The training communication process that takes place is mostly done 
during the training schedule on the mat. The trainer provides instructions during the training process for between 1.5 to 2 hours. During the training process, it is not uncommon for the coach to give instructions on examples of training techniques, both basic movements (Kihon) or competition technique movements.

The approach used in coaching communication between coaches and karate athletes is seniority and personal. This was done by the FORKI Sleman trainer to provide boundaries between the coach and the karate athletes regarding their respective roles. Meanwhile, a personal approach is taken in dealing with athletes who are still passive or lacking in training techniques. This approach is taken so that the coach can break down the obstacles experienced by athletes both psychologically and technically. This personal approach indirectly fosters the confidence of karate athletes in the coaches so that from the process of training activities and competitions the athletes will feel comfortable and calm.

The process of implementing coaching communication at FORKI Sleman Regency is to use the demonstration method and the lecture method. The lecture method is carried out to athletes in a repetitive way so that the athlete understands what the coach means in each exercise. Lectures are also carried out by athletes when the training has ended by conducting discussions and evaluations after the training process on the techniques that have been practiced by the athletes.

The demonstration method in coaching communication is giving examples of competing techniques to athletes, generally, in this method, the coach also involves athletes to feel the difference between the right technique and the wrong technique. Apart from these methods, FORKI Sleman coaches also use video matches and instructional media which are held every two months in a discussion.

Barriers to coaching communication that occurs in the process of karate are semantic and psychological barriers. Semantic barriers occur because sometimes athletes do not understand the concept of instructions given by the coach so the coach must find ways to used non-technical terms to make it easier. The psychological barrier occurs due to the lack of focus of athletes during the training process because they have to share their time and energy with their duties and roles as students.

\section{Discussion}

A good training process is also based on good communication from the coach to the athlete. Aspects that are fulfilled in the coaching process in the four sports of the research subject include consistency, credibility, respect, and the integrity of the coach. Overall communication between coaches and athletes in the four sports has shown that the coach has fulfilled all aspects of ideal communication in a training process. This fact is based on the feedback given by athletes in each sport.

The coaching communication carried out by the supervisory team of the four sports in the research subject is relatively good. The coaching team has attempted to convey instructional messages in an attempt to inculcate proper training and competition techniques. On the other hand, the coaching communication carried out also aims to generate intrinsic motivation in athletes. In the end, this intrinsic motivation will instill moral responsibility on the athlete as a provision to excel in every competition. 
The process of conveying instructional messages by coaches to athletes shows that the coach understands the characteristics of each athlete by communicating patterns both formally and informally. This understanding is then followed by a personal approach, motivating, and giving confidence to the athletes. summary the ideal model coaching communication carried out by the coach of the four sports of the research subject is followed by the picture below :

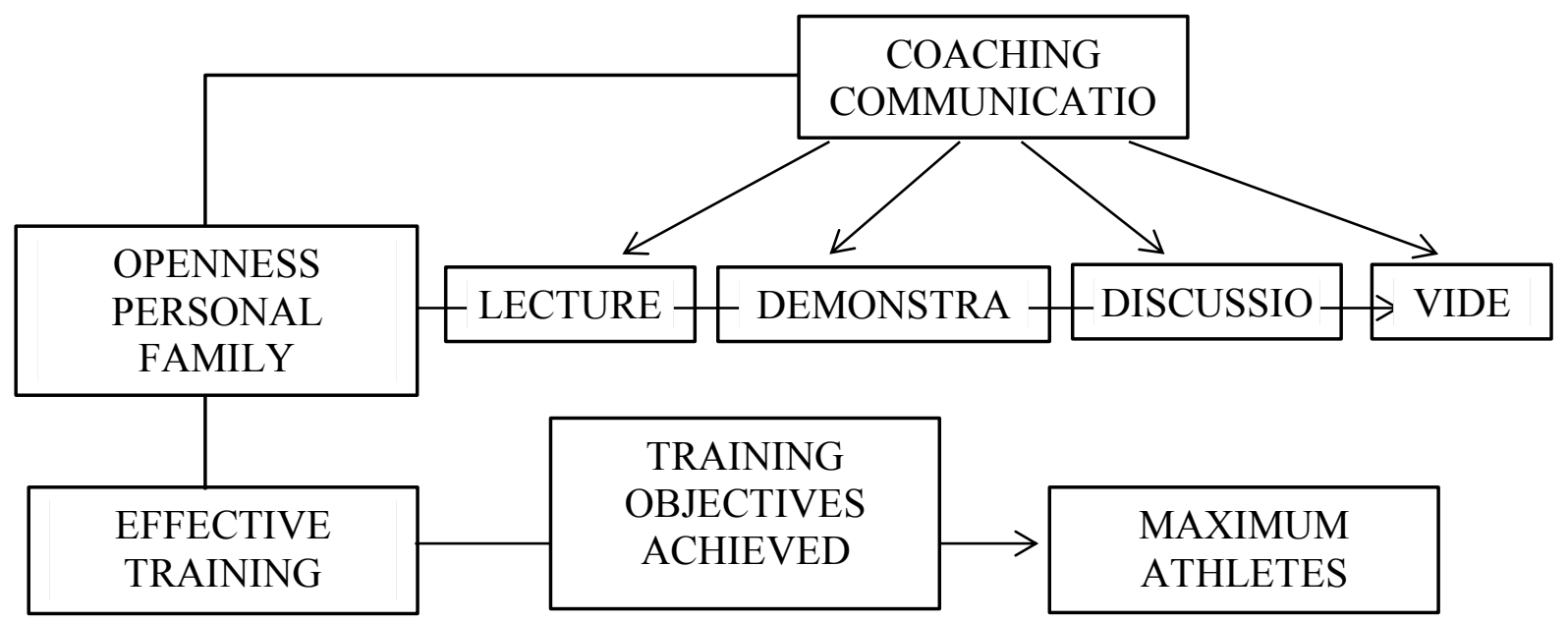

\section{CONCLUSION AND FURTHER RESEARCH}

The results showed that the form of coaching communication during and outside training is generally face-to-face. The method used in coaching communication is to use lectures and demonstrations as well as involving video media to further stimulate achievement motivation for each athlete. The approach taken in coaching communication is an open, familial, and personal approach. The three approaches are used by coaches to gain the athlete's trust in addition to being used to make it easier to understand the characteristics of each athlete. The choice of coaching communication methods and approaches has been proven to be able to motivate and build athletes' self-confidence and athletes can accept and interpret the instructional messages conveyed and desired by the coaches according to the coach's wishes.

Suggestions and recommendations that can be given in this research are on the certification of trainers for each sports trainer. Each sporting branch needs to strive for the implementation of coaching certification both at the regional or national level, this activity can be carried out by being a participant who belongs to upgrading. which is carried out by the major management or undertaking the initiative to organize training courses independently.

\section{REFERENCES}

Bogdan, Robert dan Taylor, 1992, Pengantar Metode Penelitian Kualitatif, Usaha Nasional, Surabaya 
Bompa, T.O, 2010, Theory and Methodology of Training., Dubuque: Kendall/Hunt Publishing Company

Cholik Mutohir, T, 2002, Gagasan-gagasan tentang Pendidikan Jasmani dan Olahraga, Unesa University Press: Surabaya

Davis, Louise,1, Sophia Jowett, Susanne Tafvelin, 2019, Communication Strategies: The Fuel for Quality Coach-Athlete Relationships and Athlete Satisfaction, Frontiers in Psychology, September 2019, Volume 10, Article 2156

Hadi, Rubianto, 2011, Peran Pelatih Dalam Membentuk Karakter Atlet, Jurnal Media Ilmu Keolahragaan Indonesia Volume 1. Edisi 1. Juli 2011. ISSN: 2088-6808, Unnes, Semarang

Hall M, Linder-Pelz, 2008, Meta-coaching: a methodology grounded in psychological theory. International Journal of Evidence Based Coaching \& Mentoring

Hariono, Awan, 2006, Metode Melatih Fisik Pencak Silat, Yogyakarta, Fakultas Ilmu Keolahragaan Universitas Negeri Yogyakarta

Huizinga, Johan, 1990, Homo Ludens: Fungsi dan Hakikat Permainan Dalam Budaya, Jakarta: LP3ES

Kristiyanto, Nugroho. 2012. Pembangunan Olahraga Untuk Kesejahteraan Rakyat dan Kejayaan Bangsa. Surakarta: Yumna Pustaka

Nugroho, Agung, 2010, Profil Gaya Kepemimpinan Pelatih Pencak Silat Di Daerah Istimewa Yogyakarta., Universitas Negeri Yogyakarta

Nossek, J. 1982, General Theory of Training, Lagos: National Institute For Sports, Pan African Press, Ltd

Pate, Russell R; McClenaghan, Bruce, and Rotella, 1993, Scientific Foundations of Coaching, Saunders College Publishing, Philadelphia

Pambudi, Duwi K. 2020. Analisis Standarisasi Fasilitas Gedung Olahraga Universitas Negeri Yogyakarta. Medikora, 1(19), 47

Rosca, Vlad, 2010, The Coach-Athlete Communication Process. towards a Better Human Resources Management in Sport, Management Research and Practice, Vol. 2, No. 3

Utami, Danarstuti. 2015. Peran Meningkatkan Prestasi Olahraga Indonesia Menuju Sea Games. Jurnal Olahraga Prestasi, 2(11), 56.

West, Lashell, 2016, Coach-Athlete Communication: Coaching Style, Leadership Characteristics, And Psychological Outcomes, thesis, the School of Human Movement, Sport, and Leisure Studies Bowling Green State University 